\title{
Oxygen Isotopic Variations in the Clinopyroxene from the Filicudi Volcanic Rocks (Aeolian Islands, Italy): Implications for Open-System Magma Evolution
}

\author{
A.P. Santo ${ }^{1, *}$ and A. Peccerillo ${ }^{2}$ \\ ${ }^{1}$ Dipartimento di Scienze della Terra, University of Firenze, Italy and ${ }^{2}$ Dipartimento di Scienze della Terra, University \\ of Perugia, Italy
}

\begin{abstract}
Oxygen isotope data are reported for clinopyroxene phenocrysts from volcanic rock samples from Filicudi island, Italy, with the aim of investigating mechanisms of magma evolution and mantle source characteristics in a continental arc volcano. Filicudi rocks range from calc-alkaline basalt to high-K andesite and dacite. Mafic rocks have $\mathrm{MgO}$ $\leq 6-7 \mathrm{wt} \%, \mathrm{Mg} \# \leq 60, \mathrm{Ni}<50 \mathrm{ppm}$ and $\mathrm{Cr}<200 \mathrm{ppm}$, suggesting they represent evolved melts from more primitive mantle-derived parents. Variations of $\mathrm{Sr}-\mathrm{Nd}$ isotope ratios against silica and $\mathrm{MgO}$ suggest magma evolution under opensystem. Oxygen isotope ratios on clinopyroxene phenocrysts from representative rocks are in the range $\delta^{18} \mathrm{O}_{\mathrm{cpx}}=+5.37$ to $+6.20 \%$ SMOW, corresponding to $\delta^{18} \mathrm{O}_{\text {melt }}=+5.6$ to $+6.4 \%$ and display an overall, but poorly defined, positive correlation with ${ }^{87} \mathrm{Sr} /{ }^{86} \mathrm{Sr}$ and $\mathrm{MgO}$ and a rough negative correlation with $\mathrm{SiO}_{2}$. Basalts exhibit the highest $\delta^{18} \mathrm{O}_{\text {cpx }}$ values for the volcanic series studied. Together, major, trace element and isotopic data indicate complex, multistage polybaric evolutionary processes for the Filicudi magmas. A process of fractional crystallisation, accompanied by variable degrees of crustal assimilation, best explains the isotopic and petrological data of the Filicudi volcanics. Evolution processes are inferred to have occurred in distinct magma reservoirs sited at different depths. Magma contamination affected basalts more extensively than andesitic and dacitic magmas. This was a consequence of the higher temperature and lower viscosity of mafic melts that were able to assimilate higher amounts of crustal wall rocks. Therefore, andesites and dacites preserved stable and radiogenic isotopic compositions more closely than basalts. Combined trace element and isotopic data suggest that primitive magmas at Filicudi were generated in a heterogeneous and metasomatised mantle source, which underwent contamination by slab-derived fluids. When compared with the nearby islands, isotopic variations of Filicudi rocks resemble more closely those found at Alicudi than at Salina and Vulcano. This suggests that the same kind of evolutionary processes occurred in the western island of Filicudi and Alicudi, whereas at Salina and Vulcano, in the central arc, magmas typically evolved by AFC processes, generating derivative melts that display higher Sr-O isotope compositions compared to parent basalts. These contrasting styles of magma evolution may be related to different structures of the plumbing systems of volcanic islands that were constructed in different sectors of the arc.
\end{abstract}

\section{INTRODUCTION}

Interaction between crust and upper mantle components may occur through direct contamination of mantle-derived mafic magmas during their ascent through the crust (magma contamination) or, in subduction zones by recycling of crustal materials back into the mantle wedge (source contamination). Source contamination and magma contamination are fundamentally different, but their effects on the composition of continental arc magmas can in some instances be similar and difficult to discriminate. Yet, recognising the effects of the two processes is an essentially preliminary step to achieve a better understanding of the composition of primary melts and their mantle sources as well as to shed light on magma evolutionary history in the plumbing systems of volcanoes.

Oxygen isotope investigations are crucial for revealing crustal contamination of magmas $[1,2]$. However, particular

*Address correspondence to this author at the Dipartimento di Scienze della Terra, University of Firenze, Italy; Tel +39 055 2757503; Fax: +39 055 290312; E-mail: asanto@geo.unifi.it and alba.santo@unifi.it care has to be taken in the interpretation of oxygen isotope ratios of igneous rocks because the possibility of groundmass alteration effects. Some phenocrysts (e.g., clinopyroxene, sanidine, etc.) generally provide a better measure of the oxygen isotopic composition of the original magma than do whole rocks [3], even though there is some isotopic fractionation between magma and phenocrysts during mineral crystallisation.

Additional complexities for understanding the chemical and isotopic character of magmas erupted at volcanic islands come from possibility of interaction between magmas and sea-water, a process that may occur either during eruption or inside shallow reservoirs and conduits. This is able to produce selective modification for some stable and radiogenic isotopes, leaving many other geochemical signatures of the magma unaffected.

The Aeolian volcanic arc (Southern Tyrrhenian Sea, Italy) represents an ideal locality to study processes related to magma evolution in island volcanoes developed under different tectonic conditions. This arc consists of seven main islands (Stromboli, Vulcano, Lipari, Panarea, Salina, Fili- 
cudi, Alicudi) and several seamounts (Fig. 1) that form large stratocones on the Calabria continental margin. The exposed rocks range in composition from mafic to felsic volcanics with calc-alkaline to shoshonitic and $\mathrm{K}$-alkaline affinities. Trace element abundances and ratios as well as radiogenic isotope signatures are highly variable, and it has been suggested that both source heterogeneity and complex shallowlevel evolution processes contribute to such a variability [410]. However, the relative roles of these factors and their relative importance at different volcanoes are still poorly understood.

Combined radiogenic and stable isotopic investigations can contribute significantly to the understanding of the petrogenetic processes that are responsible for compositional variations in the Aeolian Islands. Note that some of these volcanoes (Vulcano, Lipari, Stromboli and, possibly, Panarea) are currently active and, therefore, an understanding of magma evolution processes of these volcanoes is vital to construct models of their plumbing systems [11]. The Aeolian volcanoes are understudied in terms of their oxygen isotope compositions. Ellam and Harmon [6] reported whole rock Oisotope data for Volcano, Salina, and Stromboli, but determination of ${ }^{18} \mathrm{O} /{ }^{16} \mathrm{O}$ ratios of separated mineral phases is only available for the island of Alicudi [12].

This paper reports new oxygen isotope data for clinopyroxene separated from Filicudi volcanic rocks. These new Oisotope data are used together with available major, trace element and radiogenic isotope compositions of the host rocks to constrain magma evolution processes. Implications for the volcanic plumbing systems and source composition for the Island of Filicudi as well as the western-central sector of the Aeolian Arc are discussed.

\section{GEOLOGICAL SETTING AND PETROLOGY}

The Aeolian Arc consists of seven main islands (Stromboli, Vulcano, Lipari, Panarea, Salina, Filicudi, Alicudi) and several seamounts (Fig. 1), sitting on continental basement of the Calabria basement that is about $20 \mathrm{~km}$ thick [13]. The arc is typically divided into three sectors - western, central and eastern - each exhibiting different structural, petrological and volcanological characteristics [10]. The western sector is formed by the quiescent or extinct volcanic islands of Alicudi, Filicudi and Salina. These consist mostly of calcalkaline basalt to andesites, with a few dacites. However, rhyolitic pumices were erupted during the latest stages of activity at Salina. The central sector is formed by the active volcanoes of Lipari and Vulcano. These are located along the dextral NW-SE trending strike-slip Tindari-Letoianni-Malta fault (TLM; Fig. 1), an important lithospheric structure that runs from Lipari to the eastern Sicily and Malta escarpment [14]. Also Salina lies on this tectonic alignment and may be considered as also belonging to the central sector. Lipari and Vulcano consist of calc-alkaline to shoshonitic rocks with some leucite-bearing $\mathrm{K}$-alkaline products; rhyolitic rocks are abundant in the youngest (less than about $30 \mathrm{Ka}$ ) activity of these volcanoes. Finally, the eastern sector is formed by the islands of Panarea and Stromboli, which consist mostly of mafic to intermediate calc-alkaline to $\mathrm{K}$-alkaline rocks, with some rhyolites at Panarea. The eastern sector of the Aeolian Arc is characterised by the presence of a narrow Benioff

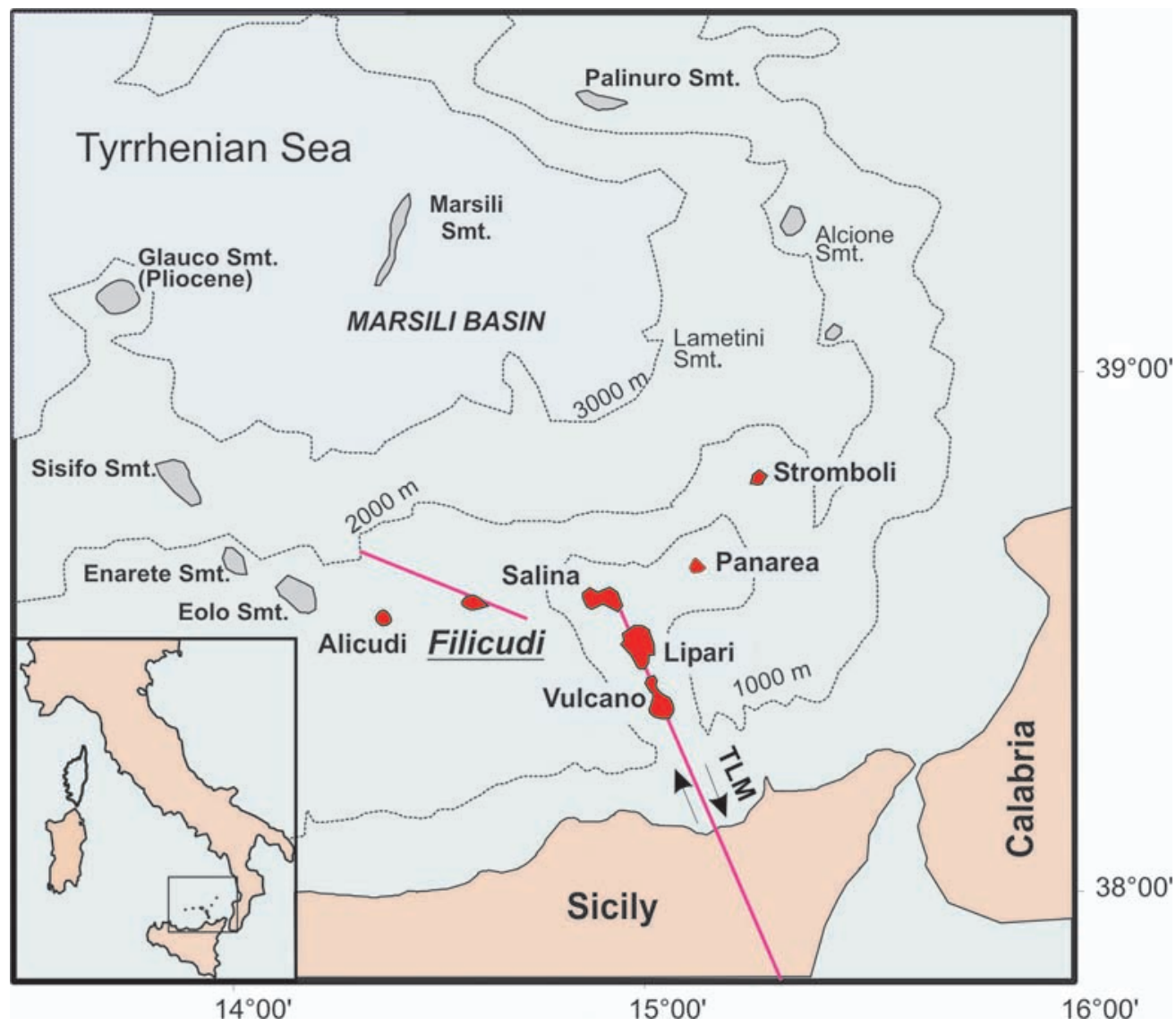

Fig. (1). Schematic map of the Aeolian volcanoes and seamounts. TLM: Tindari-Letojanni-Malta tectonic line. 
zone, with the depth of earthquake foci increasing northwestward, from Calabria to the central Tyrrhenian area. This is considered to be generated by the subduction of the Ionian plate beneath the Calabria block and the southern Tyrrhenian Sea [15].

The Aeolian volcanic rocks are characterized by highly variable trace element and radiogenic isotope signatures, with an eastward trend of increasing Sr-isotope ratios and decreasing $\mathrm{Nd}$-isotope ratios together with a parallel decrease in the ratio of Large Ion Lithophile Elements (LILE: $\mathrm{Rb}$, Th, LREE) to High Field Strength Elements (HFSE: Ta, $\mathrm{Nb}, \mathrm{Zr}, \mathrm{Hf}$ ). This regional compositional variability has been attributed to a laterally heterogeneous mantle sources $[8,16]$.

Filicudi is a composite volcano made up of lavas and pyroclastic rocks. It is developed over a $18 \mathrm{~km}$ thick continental crust [17] and consists of several, partially overlapping, eruptive centres (e.g., Monte Guardia, Monte Palmieri, Monte Montagnola, Capo Graziano, La Canna, etc.). Two of these centres (La Canna and Banco di Filicudi) are now partially or completely submerged. Oceanographic surveys of the submarine area surrounding Filicudi revealed the existence of a WNW-ESE oriented tectonic fault-system extending between the Sisifo seamount and Filicudi towards the Island of Vulcano.

The geology of the Filicudi Island has been the subject of many investigations [18]. Stratigraphic studies by Tranne [19] distinguished several formations (see Table 2) belonging to three synthems (Punta Perciato, Punta Zotta and Paleofilicudi) and two supersynthems (Punta le Grotticelle and Cala Fico). A ${ }^{40} \mathrm{Ar} /{ }^{39} \mathrm{Ar}$ age of $1.02 \mathrm{Ma}$ [20] has been measured in a lava sample from one of the lowest exposed outcrops. This would represent the oldest age found on the island and in the entire Aeolian Arc, but is inconsistent with the younger K/Ar age of $211 \pm 5 \mathrm{Ka}$ recently reported for a lava from the same stratigraphic position [21]. La Canna neck, located offshore NW of Filicudi, represents the last dated [20] activity at Filicudi.

Filicudi rocks range in composition from basalts to basaltic andesites up to high-andesites, with a few dacites (Fig. 2). They are typical calc-alkaline rocks containing a variety of magmatic and metamorphic xenoliths.

\section{PETROGRAPHY AND GEOCHEMISTRY}

The petrography and geochemistry of the Filicudi rocks have been described in detail elsewhere [18, 23, 24], and will be only briefly summarised here. All of the Filicudi rocks are highly porphyritic (30-50 vol. \%) and have a holocrystalline or hypocrystalline texture. Phenocrysts consist of plagioclase, clinopyroxene (cpx) and olivine in the basaltic and basaltic andesitic rocks. Microphenocrysts of orthopyroxene (opx) sometimes occur in accessory amounts. Plagioclase, clinopyroxene, orthopyroxene, biotite and brown hornblende represent the phenocryst mineralogy of andesites. The groundmass generally contains the same mineral phases as the phenocrysts. Ti-magnetite, ilmenite and apatite are found in accessory amounts.

Plagioclase, the most abundant mineral phase, is often complexly zoned and displays sieved or patchy zoning. Its composition lies in the wide range An $=50-95 \%$, with a bimodal distribution (andesine and bytownite) particularly evident in the andesites. Clinopyroxene is ubiquitous with variable abundance; compositions are augitic or diopsidic. Several features (e.g., zoning, Mg-number, trace element abundances) indicate chemical disequilibrium with the host magma for this mineral [23]. Subhedral or euhedral olivine crystals $(\mathrm{Fo}=60-86 \%$ ) can exhibit an iddingsitic rim or be mantled by clinopyroxene in the basalts and by orthopyroxene in basaltic andesites. Orthopyroxene $(\mathrm{En}=64-72 \%)$ is typically unzoned and, in some cases, forms reaction rim to clinopyroxene.

Basalts and basaltic andesites are characterised by high contents of $\mathrm{Al}_{2} \mathrm{O}_{3}$, low $\mathrm{Mg \#}(<60)$, and $\mathrm{Ni}$ and $\mathrm{Cr}$ abundances that are indicative of compositions far from those of mantle-equilibrated melts. $\mathrm{MgO}, \mathrm{CaO}, \mathrm{TiO}_{2}$ and $\mathrm{FeO}_{\text {total }}$ are negatively correlated with silica, whereas $\mathrm{K}_{2} \mathrm{O}, \mathrm{Na}_{2} \mathrm{O}$ and $\mathrm{P}_{2} \mathrm{O}_{5}$ display positive correlations with $\mathrm{SiO}_{2}$. LILE and HFSE increase with increasing silica content, whereas ferromagnesian trace elements have an opposite tendency. However, there is much scattering for almost all elements [23].

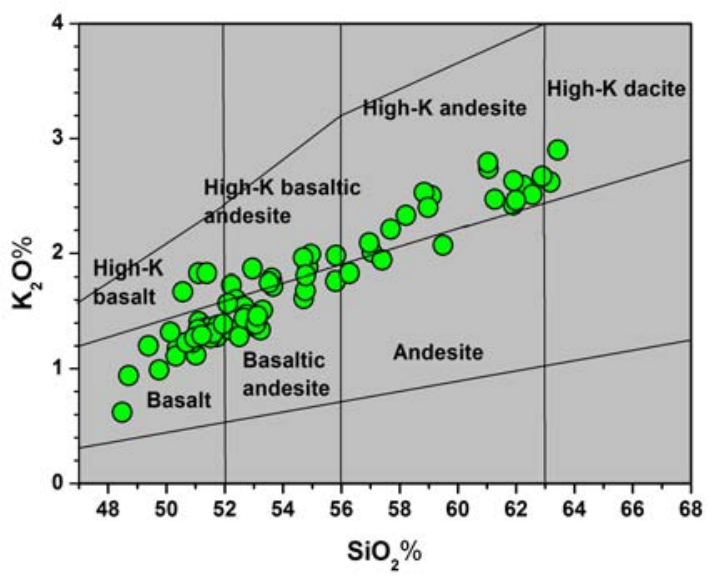

Fig. (2). $\mathrm{K}_{2} \mathrm{O}$ vs. $\mathrm{SiO}_{2}$ classification diagram (Peccerillo CMP 1976) [22] for the Filicudi rocks.

Data, plotted on water-free basis, are from Santo L 2004 [24].

Incompatible elements, such as $\mathrm{Zr}, \mathrm{Ba}, \mathrm{Rb}$ and $\mathrm{La}$, display well-defined positive correlations on inter-elemental variation diagrams, whereas other incompatible elements (Th, U, $\mathrm{Ta}, \mathrm{Nb}$, etc.) exhibit weak correlations. By comparison, other elements such as $\mathrm{Sr}, \mathrm{Ni}, \mathrm{Co}, \mathrm{Sc}, \mathrm{V}$ and $\mathrm{Cr}$ define negative, roughly curvilinear trends with incompatible elements. Ratios of ${ }^{87} \mathrm{Sr} /{ }^{86} \mathrm{Sr}$ are significantly variable $(0.704016$ 0.704740 ) and, overall, higher values are observed in the mafic rocks compared to intermediate compositions. $\mathrm{Nd}$ isotope ratios range from 0.512670 to 0.512760 and display a poorly defined negative correlation with ${ }^{87} \mathrm{Sr} /{ }^{86} \mathrm{Sr}$. Pbisotope ratios are moderately radiogenic, with ${ }^{206} \mathrm{~Pb} /{ }^{204} \mathrm{~Pb}=$ $19.31-19.67,{ }^{207} \mathrm{~Pb} /{ }^{204} \mathrm{~Pb}=15.64-15.69,{ }^{208} \mathrm{~Pb} /{ }^{204} \mathrm{~Pb}=39.11-$ $39.47[24]$.

\section{Oxygen Isotopes}

\section{Analytical Methods}

O-isotope compositions of clinopyroxene mineral separates were obtained on a commercial basis from the London 
University, Stable Isotope and Atmospheric Laboratories at Royal Holloway, University of London. The analytical methodology used is based on that of Mattey [25], subsequently modified for full automation and the analysis of oxygen gas [26]. The oxygen is liberated from samples using $\mathrm{BrF}_{5}$ reagent. Bi-products and excess reagent are trapped using liquid nitrogen and a $\mathrm{KBr}$ scrubber. Oxygen is trapped onto a molecular sieve using liquid nitrogen before being liberated for yield measurement and entry into the mass spectrometer for analysis. The weight of sample required depends on the oxygen content of the mineral so that a relatively constant amount of liberated oxygen enters the mass spectrometer. The weights used for clinopyroxenes were $1.7 \mathrm{mg}$.

In this paper, ${ }^{18} \mathrm{O} /{ }^{16} \mathrm{O}$ ratios are reported following the standard ' $\delta$ ' notation relative to the Vienna Standard Mean Ocean Water (V-SMOW) standard, the ${ }^{18} \mathrm{O} /{ }^{16} \mathrm{O}$ ratio of which is assigned a $\delta^{18} \mathrm{O}$ value of $0 \%$. The data obtained are calibrated using two standards, an internal standard (San Carlos Olivine, SCOL, which has a $\delta^{18} \mathrm{O}$ value of $4.88 \%$ o determined over 10 years of analysis), and the widely distributed GMG II (Gore Mountain Garnet) international standard (which has a reported value of $5.7 \%$ ). These standards are in turn calibrated against the international NBS-30 biotite standard, which has a known value of $+5.1 \%$ relative to SMOW. For each run, a small constant correction, normally less than $0.5 \%$ is applied to the data, based on the standard values. During the analysis period of the Filicudi clinopyroxene samples, the standards used gave values after daily correction of $+4.91 \pm 0.01 \%$ o $(1 \sigma, \mathrm{n}=2)$ for SCOL and $+5.70 \pm 0.05 \%$ o $(1 \sigma, \mathrm{n}=5)$ for GMG II. Overall the precision on replicates is better than $\pm 0.1 \%$ o $(1 \sigma)$, but the 3 samples duplicated for this study had repeatability better than $\pm 0.03 \%$ \% $(1 \sigma)$.

\section{RESULTS}

Filicudi O-isotope compositions were measured for clinopyroxenes separated from rock samples from various eruptive centres. Electron microprobe data for the analysed phases are reported in Table 1. Major, trace element and radiogenic isotope data on host rocks are reported in Table 2. Filicudi clinopyroxene compositions range from diopside to augite, and these coexist in some rock samples (e.g., Fil 10 and Fil 11). Measured pyroxene $\mathrm{O}$-isotope ratios are in the range $\delta^{18} \mathrm{O}_{\mathrm{cpx}}=+5.37$ to $+6.20 \%$. No isotopic difference is observed between clinopyroxene of different compositions, but the highest $\delta^{18} \mathrm{O}$ values are observed for pyroxene from the basalts. Assuming a cpx-melt fractionation of $+0.2 \%$ o [28-31] the oxygen isotope composition of the melts ranges between $+5.6 \%$ o to $+6.4 \%$ o, overlapping the compositions considered to be typical of mantle-equilibrated melts $[2,32]$.

Variation diagrams of $\delta^{18} \mathrm{O}_{\mathrm{cpx}} v s$. key major elements of whole rocks are shown in Fig. (3). There is a rough negative correlation of $\delta^{18} \mathrm{O}_{\mathrm{cpx}}$ with $\mathrm{SiO}_{2}$ (correlation coefficient $r=$ - 0.43) and a poorly defined positive correlation with $\mathrm{MgO}$, $\mathrm{FeO}_{\text {total }}$ and $\mathrm{CaO}(r \sim+0.3)$. Except for one sample (Fil 12), pyroxenes from the most mafic rocks exhibit higher oxygen isotopic ratios than those from andesites and dacites.

Diagrams of $\delta^{18} \mathrm{O}_{\mathrm{cpx}} v s$. key trace element abundances and ratios are shown in Figs. (4 and $\mathbf{5}$ ). The data are scattered in these plots. However, there are very rough negative

Table 1. Composition of Clinopyroxene Analysed for O Isotope

\begin{tabular}{|c|c|c|c|c|c|c|c|c|c|c|c|c|c|c|}
\hline Sample & Fil 65 & Fil 17 & Fil 76 & Fil 12 & Fil 11 & Fil 10 & Fil 199 & Fil 39 & Fil 91 & Fil 47 & Fil 116 & Fil 30 & Fil 171 & Fil 197 \\
\hline $\mathrm{SiO}_{2}$ & 53.4 & 53.6 & 51.1 & 50.6 & 51.0 & 53.6 & 52.9 & 52.0 & 52.6 & 52.5 & 51.3 & 51.6 & 51.4 & 51.2 \\
\hline $\mathrm{Al}_{2} \mathrm{O}_{3}$ & 1.7 & 2.4 & 4.3 & 4.5 & 3.6 & 2.2 & 2.6 & 2.6 & 2.9 & 2.3 & 3.9 & 4.2 & 3.2 & 2.7 \\
\hline $\mathrm{MnO}$ & 0.20 & 0.09 & 0.16 & 0.14 & 0.28 & 0.08 & 0.04 & 0.08 & 0.17 & 0.22 & 0.15 & 0.14 & 0.17 & 0.25 \\
\hline $\mathrm{MgO}$ & 17.4 & 17.2 & 16.0 & 15.2 & 15.0 & 17.4 & 17.1 & 16.6 & 17.1 & 16.1 & 16.1 & 16.2 & 15.8 & 15.8 \\
\hline $\mathrm{CaO}$ & 21.7 & 22.5 & 21.9 & 22.1 & 18.7 & 22.4 & 22.8 & 22.8 & 21.6 & 20.4 & 22.6 & 21.8 & 21.5 & 19.9 \\
\hline $\mathrm{Na}_{2} \mathrm{O}$ & 0.15 & 0.14 & 0.15 & 0.13 & 0.33 & 0.12 & 0.11 & 0.21 & 0.21 & 0.18 & 0.09 & 0.06 & 0.23 & 0.23 \\
\hline Wo & 43.6 & 45.2 & 45.6 & 45.5 & 39.0 & 45.1 & 45.8 & 46.0 & 44.0 & 41.5 & 45.9 & 44.2 & 43.7 & 40.9 \\
\hline En & 48.4 & 48.0 & 46.3 & 43.7 & 43.6 & 48.8 & 47.8 & 46.7 & 48.5 & 45.6 & 45.7 & 45.8 & 44.6 & 45.2 \\
\hline Fs & 8.0 & 6.8 & 8.1 & 10.8 & 17.4 & 6.2 & 6.4 & 7.3 & 7.5 & 12.9 & 8.4 & 9.9 & 11.7 & 13.8 \\
\hline $\mathrm{Mg} \#$ & 86.4 & 87.8 & 85.5 & 80.5 & 72.0 & 89.0 & 88.2 & 86.7 & 87.0 & 78.4 & 84.8 & 82.5 & 79.6 & 77.1 \\
\hline
\end{tabular}

Data obtained by a Jeol JXA-8600 electron microprobe at Dipartimento di Scienze della Terra, Firenze (Italy).Correction for matrix effects were made according to Bence and Albee JG 1968 [27]. 
Table 2. Geochemical and Isotopic Data for Selected Filicudi Rocks and Clinopyroxene

\begin{tabular}{|c|c|c|c|c|c|c|c|c|c|c|c|c|c|c|}
\hline \multirow{2}{*}{\begin{tabular}{|c|}
$\begin{array}{c}\text { Eruptive } \\
\text { centre }\end{array}$ \\
Formation* \\
Sample \\
\end{tabular}} & \multicolumn{2}{|c|}{$\begin{array}{l}\text { Punta dello Zucco } \\
\text { Grande }\end{array}$} & \multirow{2}{*}{$\begin{array}{c}\begin{array}{c}\text { Casa } \\
\text { Ficarisi }\end{array} \\
\text { Fil } 76\end{array}$} & \multicolumn{3}{|c|}{$\begin{array}{c}\text { Mt. Guardia } \\
\text { Filo di Lorani }\end{array}$} & \multirow{2}{*}{\begin{tabular}{c|}
$\begin{array}{c}\text { Fili di } \\
\text { Sciacca }\end{array}$ \\
Fil 199
\end{tabular}} & \multirow{2}{*}{\begin{tabular}{|c|}
$\begin{array}{c}\text { Punta } \\
\text { Lazzaro }\end{array}$ \\
Fil 39
\end{tabular}} & \multirow{2}{*}{$\begin{array}{c}\text { Canale } \\
\text { Fil } 47\end{array}$} & \multirow{2}{*}{$\begin{array}{c}\begin{array}{c}\text { Punta } \\
\text { Arinella }\end{array} \\
\text { Fil } 91\end{array}$} & \multicolumn{2}{|c|}{$\begin{array}{c}\text { Mt. Montagnola } \\
\text { Stimpagnato }\end{array}$} & \multirow{2}{*}{\begin{tabular}{c|}
$\begin{array}{c}\text { Capo } \\
\text { Graziano }\end{array}$ \\
Le Punte \\
Fil 171
\end{tabular}} & \multirow{2}{*}{\begin{tabular}{|c|} 
La Canna \\
$\begin{array}{c}\text { Scoglio } \\
\text { Montenassar }\end{array}$ \\
Fil 197
\end{tabular}} \\
\hline & Fil 65 & Fil 17 & & Fil 12 & Fil 11 & Fil 10 & & & & & Fil 116 & Fil 30 & & \\
\hline $\mathrm{TiO}_{2}$ & 0.73 & 0.56 & 0.72 & 0.64 & 0.76 & 0.78 & 0.76 & 0.77 & 0.62 & 0.69 & 0.64 & 0.52 & 0.52 & 0.83 \\
\hline $\mathrm{Al}_{2} \mathrm{O}_{3}$ & 18.60 & 16.36 & 19.06 & 13.19 & 16.85 & 19.40 & 19.26 & 19.02 & 18.11 & 19.02 & 16.20 & 17.18 & 16.29 & 16.98 \\
\hline $\mathrm{Fe}_{2} \mathrm{O}_{3}$ & 3.70 & 4.32 & 3.70 & 4.59 & 3.87 & 4.15 & 3.89 & 4.71 & 1.99 & 2.53 & 2.40 & 2.78 & 2.68 & 4.52 \\
\hline $\mathrm{FeO}$ & 5.63 & 2.32 & 5.15 & 5.92 & 6.46 & 5.87 & 5.88 & 4.14 & 4.32 & 5.12 & 3.87 & 2.59 & 2.25 & 4.33 \\
\hline $\mathrm{Na}_{2} \mathrm{O}$ & 2.35 & 3.15 & 2.32 & 1.24 & 1.99 & 2.30 & 2.50 & 2.47 & 2.82 & 2.74 & 3.64 & 3.48 & 3.44 & 2.39 \\
\hline $\mathrm{K} 2 \mathrm{O}$ & 1.32 & 2.47 & 1.11 & 0.62 & 0.94 & 1.20 & 1.23 & 1.47 & 2.40 & 1.88 & 2.42 & 2.62 & 2.90 & 1.83 \\
\hline $\mathrm{P}_{2} \mathrm{O}_{5}$ & 0.12 & 0.14 & 0.16 & 0.09 & 0.15 & 0.18 & 0.23 & 0.13 & 0.18 & 0.16 & 0.21 & 0.21 & 0.18 & 0.30 \\
\hline $\mathrm{F}$ & 0.06 & 0.04 & 0.04 & 0.04 & 0.05 & 0.06 & 0.06 & 0.10 & 0.08 & 0.06 & 0.08 & 0.10 & 0.06 & 0.08 \\
\hline $\mathrm{Cl}$ & 0.24 & 0.59 & 0.01 & 0.09 & 0.21 & 0.25 & 0.09 & 0.31 & 0.50 & 0.46 & 1.62 & 0.33 & 0.31 & 0.84 \\
\hline $\mathrm{ppm}$ & & & & & & & & & & & & & & \\
\hline $\mathrm{Rb}$ & 30 & 82 & 23 & 16 & 26 & 30 & 33 & 40 & 76 & 36 & 80 & 88 & 85 & 57 \\
\hline $\mathrm{Sr}$ & 731 & 640 & 687 & 461 & 661 & 795 & 814 & 725 & 664 & 691 & 737 & 631 & 608 & 630 \\
\hline $\mathrm{Y}$ & 17 & 13 & 17 & 17 & 19 & 20 & 20 & 21 & 20 & 19 & 19 & 17 & 15 & 20 \\
\hline $\mathrm{Tb}$ & 0.4 & 0.4 & 0.48 & 0.2 & 0.58 & 0.56 & 0.64 & 0.52 & 0.4 & 0.54 & 0.6 & 0.5 & 0.49 & 0.59 \\
\hline $\mathrm{Yb}$ & 1.53 & 1.61 & 2.00 & 1.36 & 1.70 & 1.90 & 2.00 & 2.10 & 1.76 & 2.10 & 2.34 & 2.29 & 1.80 & 1.90 \\
\hline $\mathrm{Lu}$ & 0.22 & 0.24 & n.d. & 0.23 & n.d. & n.d. & n.d. & n.d. & 0.27 & n.d. & 0.34 & 0.36 & 0.30 & 0.40 \\
\hline $\mathrm{Hf}$ & 1.60 & 2.30 & 2.00 & 1.20 & 1.80 & 1.70 & 2.00 & 2.20 & 2.90 & 2.50 & 2.50 & 2.60 & 2.60 & 2.00 \\
\hline Th & 3.7 & 7.4 & 3 & 1.6 & 3 & 3.5 & 4.1 & 4.5 & 7.8 & 5.9 & 7.7 & 10 & 8.7 & 4.5 \\
\hline $\mathrm{U}$ & 1.60 & 2.80 & 1.02 & 0.40 & 0.74 & 0.90 & 0.95 & 1.30 & 3.40 & 1.80 & 3.00 & 3.90 & n.d. & n.d. \\
\hline $\mathrm{Sc}$ & 33 & 17 & 30 & 70 & 46 & 33 & 27 & 32 & 20 & 28 & 15 & 13 & 17 & 37 \\
\hline $\mathrm{Cr}$ & 23 & 15 & 68 & 150 & 99 & 18 & 21 & 15 & 12 & 16 & 1.3 & 2.2 & 12 & 184 \\
\hline Co & 30 & 14 & 30 & 47 & 43 & 39 & 32 & 32 & 19 & 27 & 15 & 15 & 13 & 32 \\
\hline$\delta^{18} \mathrm{O}_{\text {cpx }}$ & 5.54 & 5.77 & 6.20 & 5.55 & 5.67 & 5.82 & 5.93 & 5.63 & 5.76 & 5.72 & 5.37 & 5.47 & 5.63 & 6.01 \\
\hline${ }^{87} \mathrm{Sr} /{ }^{86} \mathrm{Sr}$ & 0.704344 & 0.704358 & 0.704450 & 0.704362 & 0.704730 & 0.704290 & 0.704580 & 0.704380 & 0.704434 & 0.704650 & 0.704016 & 0.704288 & 0.704360 & 0.704440 \\
\hline${ }^{143} \mathrm{Nd} / /{ }^{144} \mathrm{Nd}$ & 0.512750 & 0.512744 & 0.512733 & 0.512719 & 0.512666 & 0.512757 & 0.512722 & 0.512756 & 0.512726 & 0.512684 & 0.512739 & 0.512700 & 0.512724 & n.d. \\
\hline${ }^{206} \mathrm{~Pb} /{ }^{204} \mathrm{~Pb}$ & 19.672 & 19.464 & 19.500 & 19.404 & 19.412 & 19.460 & 19.340 & 19.674 & 19.531 & 19.540 & 19.349 & 19.313 & 19.464 & n.d. \\
\hline${ }^{207} \mathrm{~Pb} /{ }^{204} \mathrm{~Pb}$ & 15.673 & 15.671 & 15.650 & 15.653 & 15.667 & 15.673 & 15.640 & 15.686 & 15.671 & 15.650 & 15.670 & 15.677 & 15.661 & n.d. \\
\hline${ }^{208} \mathrm{~Pb} /{ }^{204} \mathrm{~Pb}$ & 39.447 & 39.313 & 39.230 & 39.205 & 39.247 & 39.294 & 39.110 & 39.472 & 39.320 & 39.260 & 39.207 & 39.214 & 39.263 & n.d. \\
\hline
\end{tabular}

Data are from Santo L 2004 [24] except F, Cl and O isotope (this work). F and Cl were analysed at Activation Laboratories, Ancaster, Canada. F was determined by specific electrode methods.

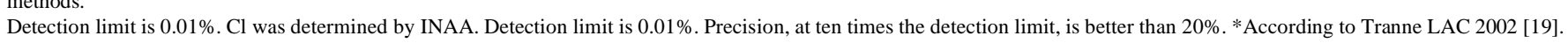



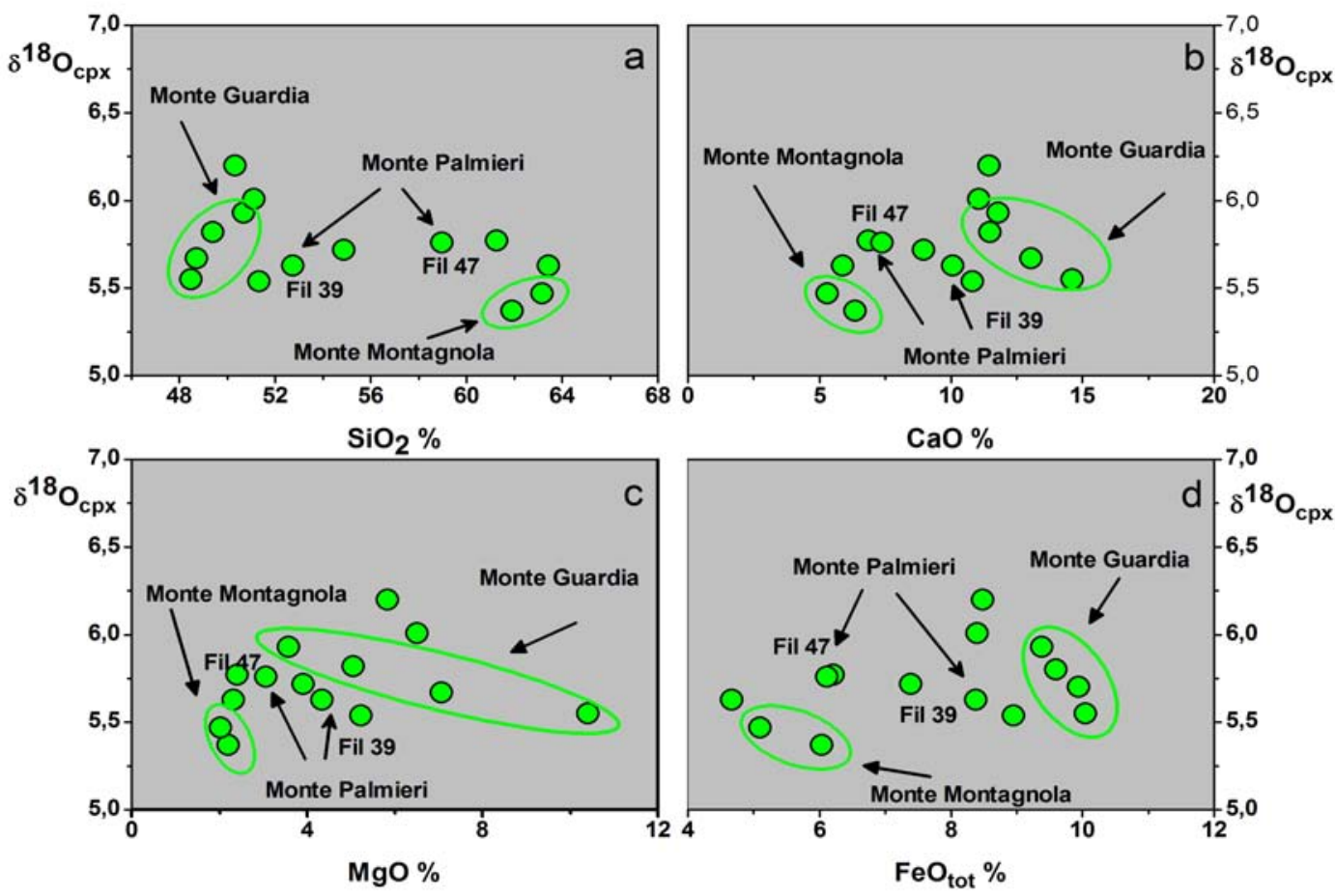

Fig. (3). Variation diagrams of $\delta^{18} \mathrm{O}_{\mathrm{cpx}} v s$. major elements. For further explanation see text.

correlations of $\delta^{18} \mathrm{O}_{\mathrm{cpx}}$ with incompatible elements (e.g., Th, $\mathrm{Nb}$ ) including $\mathrm{F}$ and $\mathrm{Cl}$, and poorly defined positive correlations of $\delta^{18} \mathrm{O}_{\mathrm{cpx}}$ with compatible elements (e.g., Ni). Incompatible element ratios LILE/HFSE (e.g., $\mathrm{Ba} / \mathrm{Nb}, \mathrm{La} / \mathrm{Nb}$, $\mathrm{La} / \mathrm{Zr}$, etc.) and LILE/LILE (e.g., Th/La) show scattered distributions when plotted against $\delta^{18} \mathrm{O}_{\mathrm{cpx}}$ (Fig. 5), except for a very poorly defined negative covariation with $\mathrm{Rb} / \mathrm{Sr}$ $(r=-0.32)$.

When single volcanic centres from Filicudi are considered separately, correlations between $\mathrm{O}$-isotope ratio and geochemical parameter variations change dramatically. For instance, samples Fil 10, Fil 11, Fil 12 and Fil 199 from Monte Guardia centre display a very well-defined positive correlation of $\delta^{18} \mathrm{O}_{\mathrm{cpx}}$ with $\mathrm{SiO}_{2}$ (Fig. 3a) and a negative correlation versus $\mathrm{MgO}$ (Fig. 3c). Similar trends are observed for samples from other centres, e.g., Fil 39 and Fil 47 from Monte Palmieri, and Fil 116 and Fil 30 from Monte Montagnola.

Fig. (6) shows variation of $\delta^{11} \mathrm{O}_{\mathrm{cpx}} v s .{ }^{87} \mathrm{Sr} /{ }^{86} \mathrm{Sr}$ and ${ }^{143} \mathrm{Nd} /$ ${ }^{144} \mathrm{Nd}$. There is a poorly define positive correlation between $\mathrm{O}$ - and Sr-isotope ratios $(r=+0.46)$ and no correlation between $\mathrm{O}$ - and Nd- isotopes $(r=0.07)$.

\section{DISCUSSION}

The oxygen isotopic composition of Filicudi clinopyroxenes shows significant variations, with values of $\delta^{18} \mathrm{O}_{\mathrm{cpx}}$ ranging from +5.37 to $+6.20 \%$. Since there is a modest Oisotopic fractionation between melt and clinopyroxene during crystallisation, these values are inferred to correspond to values for $\delta^{18} \mathrm{O}_{\text {melt }}=5.6 \%$ to $6.4 \%$.

Whole rocks hosting the analysed clinopyroxenes also show moderate but significant variations in both Sr- and Nd- isotopic compositions and incompatible trace elements ratios. This feature may attest to either an origin in a heterogeneous source or post-partial melting interaction between magma and wall rocks within the crust. Such a dilemma applies not only to the Filicudi volcanic complex but to most, if not all, magmas erupted in continental environments [16, 3335].

\section{Open-System Magma Evolution}

Previous studies have shown that the Filicudi magmas evolved via fractional crystallisation processes plus some interaction with crustal rocks that occurred in several smallsize magma chambers [24]. Variation of radiogenic and stable isotope ratios, however, can be related to both magma contamination by crustal wall rocks and to mantle source heterogeneity. Interaction between magma and seawater is an additional process that may have important effects on isotopic compositions of rocks in volcanic islands. Thus, it is crucial for the understanding of volcanic systems to place constraints on the role of these processes.

Magma contamination by upper crust generally generates moderate variation of ${ }^{87} \mathrm{Sr} /{ }^{86} \mathrm{Sr}$, especially in the Sr-rich mafic and intermediate magmas; however, much more dramatic modifications are observed for ${ }^{18} \mathrm{O} /{ }^{18} \mathrm{O}$ ratios (e.g., James, AREPS) [36]. This contrasting behaviour of $\mathrm{Sr}-\mathrm{O}$ isotopes is an effect of the much higher absolute abundance of $\mathrm{Sr}$ in the magmas $(\mathrm{Sr} \sim 800-1000 \mathrm{ppm})$ than in the crustal rocks $(\mathrm{Sr}$ $\sim$ 100-150 ppm), which makes Sr-isotope ratios of magmas to be poorly susceptible to crustal contamination processes. In contrast, oxygen abundances are comparable in the magmas and upper crustal rocks; therefore, oxygen isotope composition of magmas changes more readily than $\mathrm{Sr}$ isotopes 

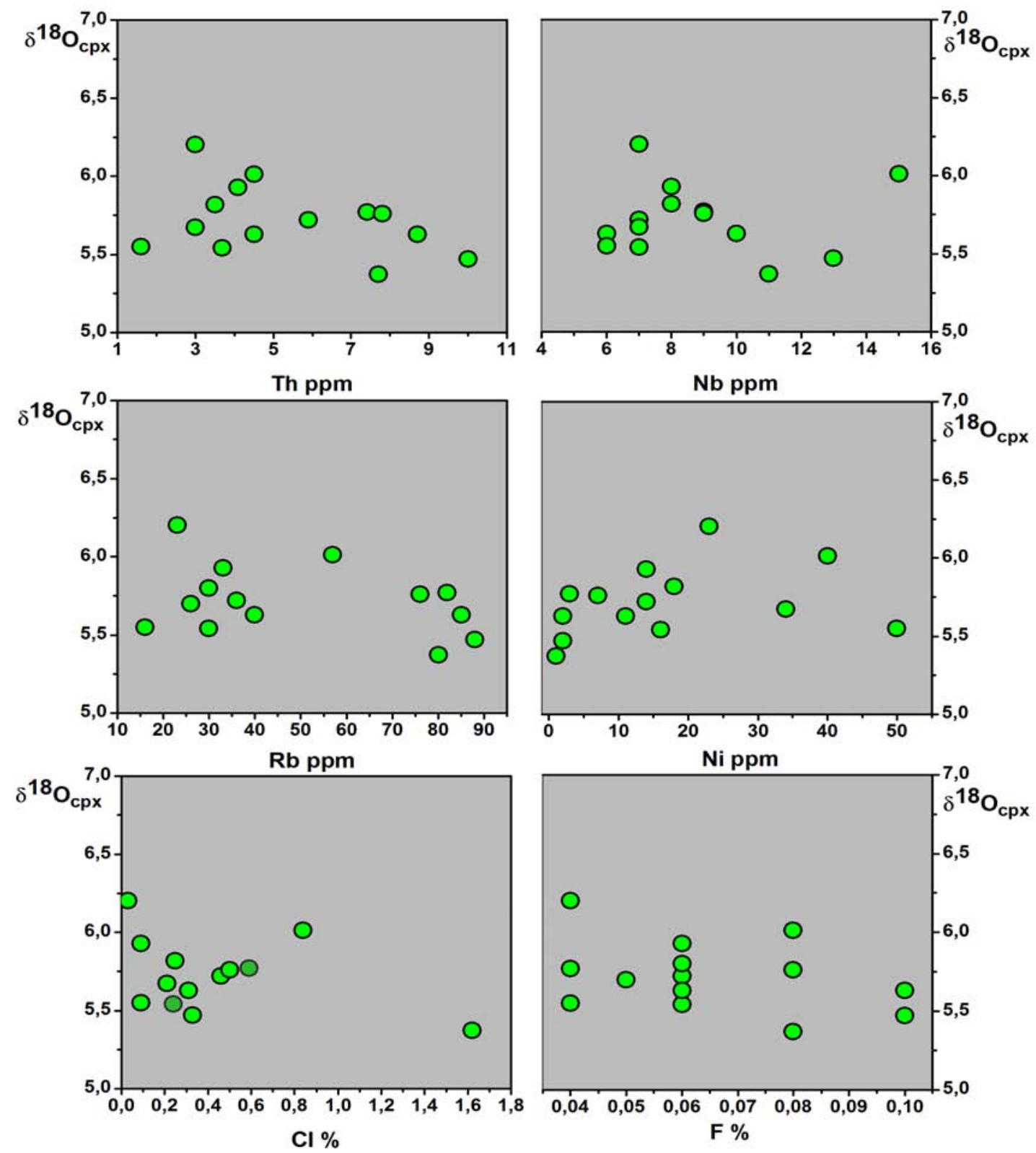

Fig. (4). Variation diagrams of $\delta^{18} \mathrm{O}_{\mathrm{cpx}} v s$. trace elements.

during magma-crust interaction. The opposite effect is observed during mantle contamination by upper crustal rocks (e.g., during subduction of pelagic sediments). Mantle rocks are strongly depleted in $\mathrm{Sr}(\sim 15-20 \mathrm{ppm})$ and $\mathrm{Nd}(\sim 1.0-1.3$ ppm), but have comparable oxygen concentration than subducted crustal rocks. This produces strong variations of Sr$\mathrm{Nd}$ isotope systematics but little O-isotope modification in the contaminated mantle (see also following paragraph and Fig. 7).

Modalities of magma-crust interaction are variable and produce different trends of geochemical and isotopic variations in the contaminated melts. Incorporation of bulk crust into the magma and coupled assimilation and fractional crystallisation (AFC) produce a positive ${ }^{87} \mathrm{Sr} /{ }^{86} \mathrm{Sr}-\delta^{18} \mathrm{O}$ correlation and also an increase of both isotope ratios with $\mathrm{SiO}_{2}$; in contrast, both $\mathrm{Sr}$ - and $\mathrm{O}$-isotope ratios correlate negatively with $\mathrm{CaO}$ and $\mathrm{MgO}$ [37]. These trends are particularly well defined when compositional evolution takes places in a single magma chamber where intermediate and silicic melts derive from a single type of mafic parent that continuously assimilates crustal rocks during fractional crystallisation.

Several studies have shown that the extent of interaction between magmas and crustal rocks is not as simple as described by bulk assimilation or AFC processes, depending on several factors such as the structure of the plumbing system of the volcano and temperature and viscosity of magmas [38, 39]. For instance, very hot and poorly viscous mafic melts may be able to dissolve larger amounts of crustal rocks than evolved magma, thus undergoing stronger isotopic modifications than felsic melts. These have been described as 'Assimilation plus Equilibrium Crystallisation' (AEC) by some authors, since incorporation of crustal material is not accompanied by fractionation of the crystallising minerals [40]. Overall, the result of AEC is a decrease of $\mathrm{Sr}$ - and O- isotope 

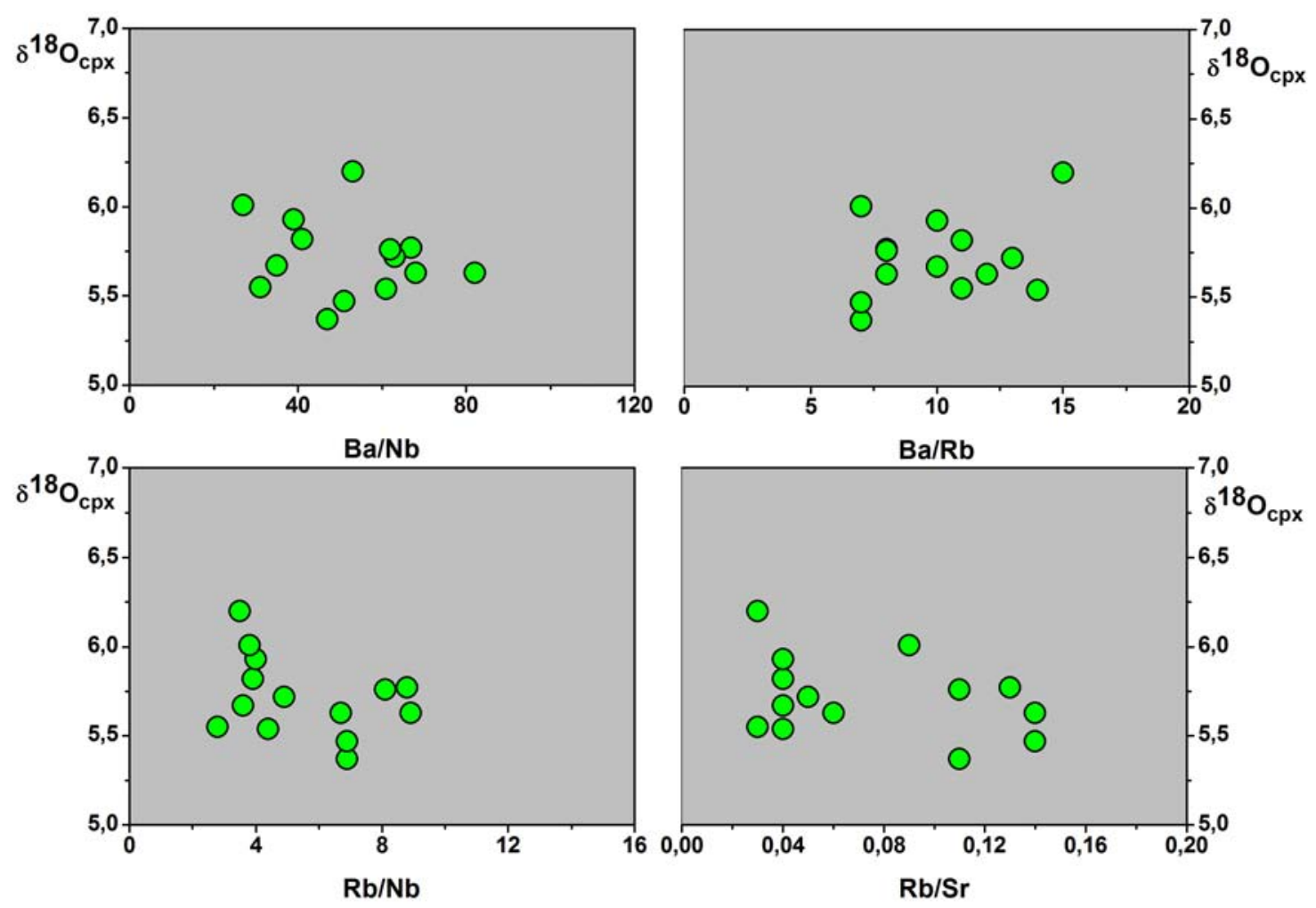

Fig. (5). Variation diagrams of $\delta^{18} \mathrm{O}_{\mathrm{cpx}} v s$. key trace element ratios.

ratios from mafic to felsic rocks, which is the opposite of what expected for bulk assimilation and for AFC. Negative correlation of ${ }^{87} \mathrm{Sr} /{ }^{86} \mathrm{Sr}$ and $\delta^{18} \mathrm{O}$ versus $\mathrm{SiO}_{2}$ has been observed for several volcanoes, including Alicudi [41, 42, 39], the Phlegrean Fields [10] as well as other volcanic suites emplaced in continental settings [40, 43, 35].

An important characteristic of the Filicudi suite is that, whereas some single volcanic centres have typical AFC trends (e.g., Monte Guardia), overall there are positive correlations of $\delta^{18} \mathrm{O}$ vs. $\mathrm{MgO}, \mathrm{FeO}_{\text {total }}$ and $\mathrm{CaO}$, and there is a tendency of ${ }^{87} \mathrm{Sr} /{ }^{86} \mathrm{Sr}$ and $\delta^{18} \mathrm{O}$ to decrease with increasing silica contents (see Fig. 3). These contrasting characteristics suggest that, whereas AFC was an important mechanism at local scale beneath single volcanic centres, other processes were predominant at the larger scale of the island. These largerscale processes obliterated the local AFC trends and generated a poorly-defined decrease of $\mathrm{O}$ - and $\mathrm{Sr}$-isotope ratios from mafic to felsic compositions. This situation has important implications for models of the plumbing system of Filicudi volcanoes.

Crystal-chemistry data on clinopyroxene from Filicudi has been reported by Nazzareni [44] who showed that this mineral has variable cell volumes, which is suggestive of polybaric crystallisation in shallow to deep-crust magma chambers. Data reported by Santo [24] suggest evolution in different reservoirs for the various eruptive centres of the Island of Filicudi. These studies, together with the isotopic variations discussed above, support the idea that there are various magma reservoirs sited at different depths beneath the Filicudi island. Positive $\delta^{18} \mathrm{O}-\mathrm{SiO}_{2}$ correlations observed for some individual volcanic centres were generated by AFC in small local magma reservoirs. However, the overall nega- tive correlation of $\delta^{18} \mathrm{O}$ and $\mathrm{SiO}_{2}$ for Filicudi suggests that mafic magmas more strongly assimilated continental crust. These latter processes could have occurred in deep magma chambers, in which continuous assimilation and mixing with
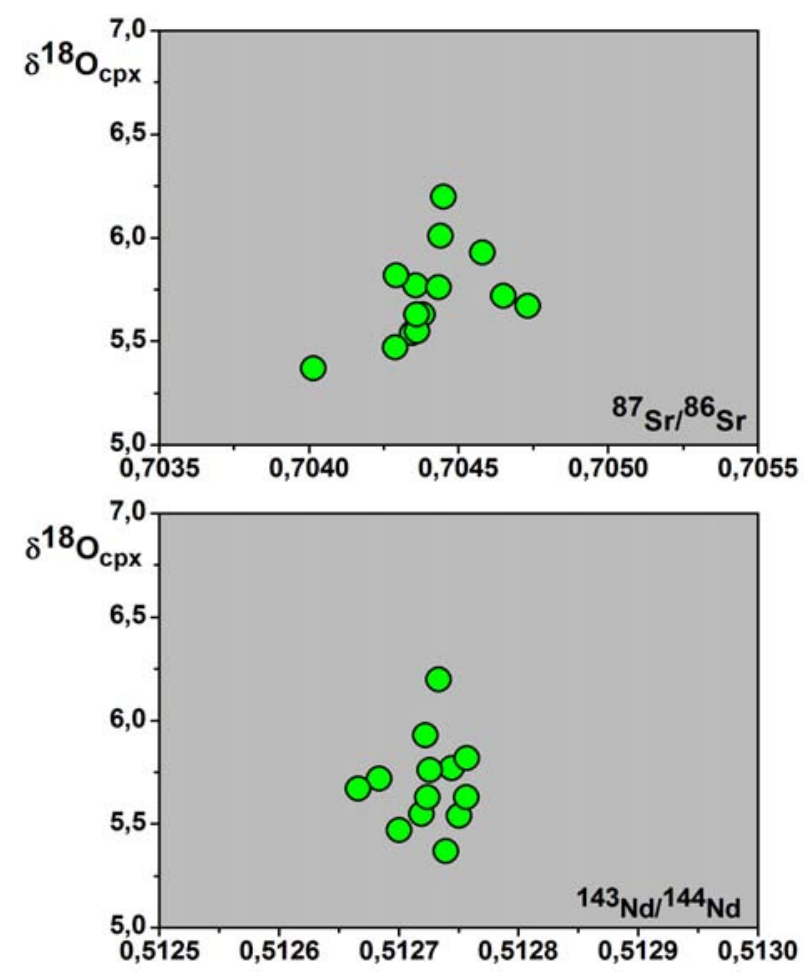

Fig. (6). Variation diagrams of $\delta^{18} \mathrm{O} v s .{ }^{87} \mathrm{Sr} /{ }^{86} \mathrm{Sr}$ and ${ }^{143} \mathrm{Nd} /{ }^{144} \mathrm{Nd}$. 
new and very hot magma generated highly contaminated mafic melts. Such a process of high degrees of crustal assimilation by mafic melts would offset the typical AFC trend, which is only observed by particular volcanic suites of some eruptive centres. Therefore, the plumbing system of Filicudi island, where several partially superimposed distinct volcanic centres have an E-W alignment, is best explained as consisting of several small reservoirs where magma evolution processes were dominated by different mechanisms, thus fitting the model of polybaric fractionation in several small reservoirs suggested by Nazzareni [44] and Santo [24].

Finally, seawater-magma interaction could produce variation of Sr- and O-isotope ratios at Flicudi. In fact, seawater has higher ${ }^{87} \mathrm{Sr} /{ }^{86} \mathrm{Sr}(\sim 0.709)$ and lower $\delta^{18} \mathrm{O}_{\text {SMOw }}$ (typically, around zero) than any of the Aeolian Arc magmas. However, seawater is also rich in $\mathrm{Cl}$ and the lack of correlation between $\mathrm{Sr}-\mathrm{O}$ isotopic ratios versus $\mathrm{Cl}$ (not shown), excludes a significant role of such a process.

\section{Source Heterogeneity}

Geochemically heterogeneous compositions are believed to be common in the mantle sources of arc magmas. These result from various processes, including different amounts and nature of crustal components (i.e., fluids, sediments, MORB melts, etc.) added to the wedge via subduction (mantle metasomatism or contamination) and the composition of pre-metasomatic peridotite [45]. Particularly important for the geochemical variability of mantle sources beneath volcanic arcs are the ratios of LILE/HFSE. High values of these ratios are typical of arc magmas and are considered to result from selective metasomatic addition of LILE with respect to HFSE by fluids released from undergoing slabs [46]. Sr-Nd$\mathrm{Pb}$ isotope compositions can be also modified during mantle contamination, especially when upper crustal components (e.g., sediments) are involved in subduction, a process that is strongly probable for the Aeolian Arc [16]. However, both LILE/HFSE ratios and radiogenic isotope signatures can be also modified by magma contamination.

The Filicudi rocks have shown variable trace element ratios, both LILE/LILE and LILE/HFSE. Except for $\mathrm{Rb} / \mathrm{Sr}$ ratios, which can be easily modified by plagioclase fractionation or accumulation, none of the observed incompatible trace element ratios is correlated with radiogenic isotopic variations. This suggests that variations of trace element ratios, especially LILE/HFSE, do not depend on magma assimilation processes but likely reflect source heterogeneity beneath the Filicudi volcano.

We suggest that different amounts of subduction-derived fluids were added to the mantle wedge beneath Filicudi Island to produce variable values of LILE/HFSE ratios in the source, which subsequently, during partial melting, were inherited by magmas erupted at the surface. It is unlikely that there was a role for upper crustal material such as subducted sediments in this process, since $\mathrm{Sr}$ - and Nd-isotope compositions for Filicudi lavas are in the field of normal mantle values and show moderate variations which, as demonstrated earlier, are the effect of shallow level magmatic evolution. This implies that the subduction fluids were isotopically homogenous and had relatively unradiogenic Sr-isotope compositions. These characteristics suggest that an oceanic type crust was subducted beneath the western branch of the Aeolian Arc. Our conclusions are inconsistent with Doglioni TN 2001 [47] who suggests that a continental type crust is subducting beneath the western Aeolian Arc, but agree with De Astis T 2003 [48] who suggests oceanic crust subduction.

\section{COMPARISON WITH NEARBY AEOLIAN ISLANDS OF ALICUDI AND SALINA}

The Aeolian Arc volcanics display a wide range of radiogenic and stable isotope compositions at regional scale [4-6, 16, 49]. Most of the observed variability, especially for radiogenic isotopes, reflects source heterogeneity $[4,8,16]$. However, there is also an important role of interaction between magma and crust. This may be different in style and intensity in the various volcanic islands, depending on the local stress regime, the nature of the bedrock and the structure of the plumbing system of various volcanoes.

Fig. (7) shows ${ }^{87} \mathrm{Sr} /{ }^{86} \mathrm{Sr} v$ s. $\delta^{18} \mathrm{O}$ variation of Filicudi and the nearby islands of Alicudi and Salina. Compositions of Stromboli and Vulcano are also reported. Oxygen isotopic data for Alicudi and Filicudi have been determined on separated clinopyroxenes and the data plotted in Fig. (7) have been corrected for fractionation to represent values of the liquids [12]. Data for Salina, Vulcano and Stromboli have been determined for whole rocks $[6,50]$. Mixing trends between basaltic magmas and crust (solid line) and mantle and crust (dashed line) are also shown in Fig. (7). Values of $\delta^{18} \mathrm{O}$ $=+16 \%$, and ${ }^{87} \mathrm{Sr} /{ }^{86} \mathrm{Sr}=0.725$ have been assumed for crust end-member [51]. As explained earlier, mixtures of crust and mantle (i.e., addition of continental crust to the mantle wedge) have very variable $\mathrm{Sr}$-isotope ratios that depend on the amounts of crustal end-member. In contrast, O-isotope variations are much greater during mixing between magma and upper crust.

There are strong differences in the absolute values of isotopes and their variation trends in the Aeolian islands. Filicudi and Alicudi display rather small variations of $\mathrm{O}$ isotope ratios. Moreover, there is a rough negative $\delta^{18} \mathrm{O}-\mathrm{SiO}_{2}$ and a positive $\delta^{18} \mathrm{O}-\mathrm{MgO}$ correlation, as discussed earlier $[12,41]$. In contrast, the O-isotope data for whole rocks from Salina, Vulcano and Stromboli are much higher and show stronger variation through the eruptive sequence and, moreover, the Salina, Vulcano and Stromboli rocks show very well defined positive correlations of $\delta^{18} \mathrm{O} \%$ ovs. $\mathrm{SiO}_{2}[6,50]$. These trends do not change if only mafic and intermediate rocks are considered and are typical of AFC processes [37]. Finally, Sr-isotope ratios for Salina, Vulcano and Filicudi are very similar and, overall, are higher than at Alicudi but much lower than at Stromboli.

Although whole rocks O-isotope compositions may undergo modification by secondary alteration, the fresh (i.e., unaltered) nature of rocks $[6,50]$, as well as the well-defined $\delta^{18} \mathrm{O}-\mathrm{SiO}_{2}$ and $\delta^{18} \mathrm{O}-\mathrm{MgO}$ trends indicate that the measured ${ }^{18} \mathrm{O} /{ }^{16} \mathrm{O}$ ratios are close to the pristine magmatic values. Keeping this in mind, it can be safely inferred that the very different trends of O-isotope variation strongly suggest different type and intensity of magma evolution processes at Filicudi and Alicudi with respect to Salina, Vulcano and Stromboli, i.e, AEC at Filicudi and Alicudi and AFC in the other islands. 


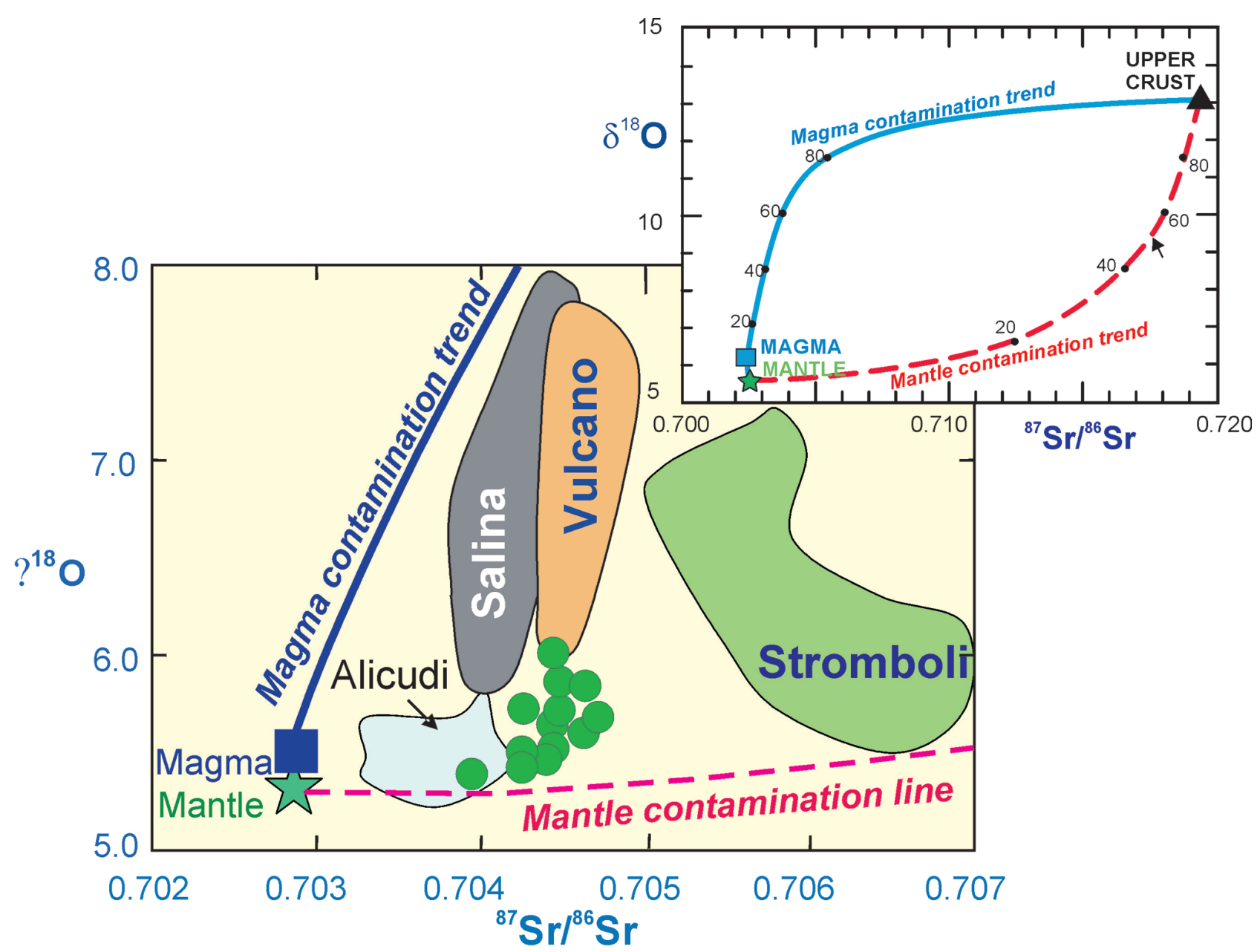

Fig. (7). Variation diagram of ${ }^{87} \mathrm{Sr} /{ }^{86} \mathrm{Sr} v s . \delta^{18} \mathrm{O}$ for the Filicudi clinopyroxenes (full circles) and for some Aeolian islands. The full and dashed lines are portions of the magma contamination and mantle contamination trends fully reported in the inset. Inset: calculated mixing trends between mantle (star) and crust (full triangle) and between basaltic magma (full square) and crust. Magma-crust mixing (magma contamination trend; full line) produces distinct trend of $\mathrm{Sr}-\mathrm{O}$ isotope variation than mixing between magma and crust (mantle contamination trend; dashed line). Numbers along the trend indicate amount of crustal material. For further explanation, see text.

Salina and Vulcano show comparable Sr-isotope ratios to Filicudi, but display much more variable and higher ${ }^{87} \mathrm{Sr}$ values, falling along magma-crust mixing trend in a ${ }^{87} \mathrm{Sr} /$ ${ }^{86} \mathrm{Sr}-{ }^{87} \mathrm{Sr}$ plot. This suggests that the $\mathrm{Sr}$-isotope composition of mantle sources at Salina, Vulcano and Stromboli are similar, but distinctly different compositions are present beneath Alicudi and Filicudi. Stromboli has significantly higher Srisotope ratios than the central and western islands, but has a range of $\delta^{18} \mathrm{O}$ values similar to Salina and Vulcano. This supports conclusions of several studies that source compositions are isotopically distinct in the western-central and eastern sectors of the Aeolian Arc [8, 9].

The distinct type of evolution at Alicudi-Filicudi with respect to Salina-Vulcano-Stromboli may be a consequence of the different structural positions of these islands and/or on the different types of crustal material beneath the volcanoes. Alicudi and Filicudi are on the western branch of the arc, which was constructed on WNW-ESE tear faults. The volcanism in the eastern sectors develops on a NNW-SSE striking lithospheric discontinuity [48]. Vulcano and the island of
Lipari are on the Tindari-Letojanni-Malta fault, which is a primary tectonic feature of the Aeolian Arc that divides the extinct western sector from the active central and eastern sector of the arc. Salina is at the crossing point between WNE-ESE trending faults and the NW-SE trending TindariLetojanni-Malta (TLM) transcurrent fault system. A series of graben and horst structures were developed along the TLM fault system [52], forming pull-apart basins. Horst-graben structures favour the formation of intracrustal magma chambers, most probably at the margins of tilted crustal blocks. In these chambers evolutionary processes (both fractional crystallisation and AFC) are very efficient giving abundant silicic products, as observed, for instance, in the Ethiopian Rift Valley [53]. AFC processes in these reservoirs were the prevailing mechanism of magmatic compositional evolution, with formation of abundant acidic rocks. It is important to note that whereas Alicudi and Filicudi consist entirely of mafic and intermediate magmas with a few dacites, rhyolitic rocks occur at Salina during the late stages of activity and are abundant at Vulcano [54]. 
Another possibility, not necessarily an alternative, is that the type of rocks that host magma chambers had different compositions in the various islands. This may well apply to the western and central sectors of the Aeolian Arc. The south-western boundary between the Calabro-Peloritano basement and the Sicilian Maghrebides terrains on the mainland Sicily is located just south of the Salina-Lipari-Vulcano alignment. Although this limit is not obvious beneath the Aeolian islands, it is possible that whereas Salina, Lipari, Vulcano and the eastern arc lie on the Calabro-Peloritano basement, different types of bedrock are present beneath Filicudi and Alicudi. The fact that abundant granitoid xenoliths have been erupted at Salina, but, to our best knowledge, not at Filicudi and Alicudi, could be an evidence for such a situation.

\section{CONCLUSIONS}

Filicudi volcanic rocks have clinopyroxenes of variable O-isotope compositions that overlap or are slightly higher than those of mantle-equilibrated melts, indicating some assimilation of upper crust by host magmas during their ascent to the surface. Overall, $\delta^{18} \mathrm{O}$ values are higher in the basalts than in the andesites and dacites, indicating that magma contamination by upper crust was stronger in the mafic melts. This may be a consequence of higher temperature and lower viscosity of basaltic magmas, which favoured interaction with wall rocks and their dissolution and incorporation. In contrast, when single volcanic centres are taken into consideration, oxygen isotopic ratios increase with increasing silica contents, suggesting that AFC operated within single magma chambers beneath the various volcanic centres making up the Filicudi Island. Variable ratios of incompatible elements seem to be unrelated to evolutionary processes, indicating some heterogeneity in the source.

When compared with the nearby islands of Alicudi, Salina and Vulcano, the Filicudi rocks are more similar to Alicudi where the same types of evolutionary processes have been envisaged. Instead, at Salina and Vulcano AFC processes appear to be more active, determining evolution of magmas up to rhyolitic composition. The different styles of magma evolution in the various islands are suggested to depend on the different structure of their plumbing systems. These are an effect of the structural position of the different island with respect to the main fault systems affecting the Aeolian Arc. However, modification of the nature of the basement rocks in the different arc sectors may also have an important role on the style of magma evolution in the different islands.

\section{ACKNOWLEDGEMENTS}

This research has been financially supported by the University of Perugia and by MIUR (Cofin 2004).

\section{REFERENCES}

[1] Taylor, H.P. The effect of assimilation of country rocks by magmas on ${ }^{18} \mathrm{O} /{ }^{16} \mathrm{O}$ and ${ }^{87} \mathrm{Sr} /{ }^{86} \mathrm{Sr}$ systematics in igneous rocks. Earth Planet Sci. Lett., 1980, 47, 243-254.

[2] Hoefs, J. Stable Isotope Geochemistry. Springer, Heidelberg, 2001.

[3] Eiler, J.M.; Crawford, A.; Elliott, T.; Farley, K.A.; Valley, J.W.; Stolper, E.M. Oxygen isotope geochemistry of oceanic-arc lavas. $J$. Petrol., 2000, 41(2), 229-256.

[4] Ellam, R.M.; Menzies, M.A.; Hawkesworth, C.J.; Leeman, W.P.; Rosi, M.; Serri, G. The transition from calc-alkaline to potassic orogenic magmatism in the Aeolian Islands, Southern Italy. Bull. Volcanol., 1988, 50, 386-398.

[5] Ellam, R.M.; Hawkesworth, C.J.; Menzies, M.A.; Rogers, N.W. The volcanism of southern Italy: the role of subduction and the relationships between potassic and sodic alkaline volcanism. J. Geophys. Res., 1989, 94, 4589-4601.

[6] Ellam, R.M.; Harmon, R.S. Oxygen isotope constraints on the crustal contributions to the subduction-related magmatism of the Aeolian Island, Southern Italy. J. Volcanol. Geotherm. Res., 1990, 44, 105-122.

[7] Francalanci, L.; Manetti, P.; Peccerillo, A. Volcanological and magmatological evolution of Stromboli volcano (Aeolian Islands): the roles of fracrional crystallization, magma mixing, crustal contamination, and source heterogeneity. Bull. Volcanol., 1989, 51, 355-378.

[8] Francalanci, L.; Taylor, S.R.; Mc Culloch, M.T.; Woodhead, J. Geochemical and isotopic variations in the calc-alkaline rocks of Aeolian Arc (Southern Italy): constraints on the magma genesis. Contrib. Mineral. Petrol., 1993, 113, 300-313.

[9] Peccerillo, A. Geochemical affinities between Vesuvius, Phlegrean Fields and Stromboli volcanoes: petrogenetic, geodynamic and volcanological implications. Mineral. Petrol., 2001, 73, 93-105.

[10] Peccerillo, A. Plio-Quaternary volcanism in Italy. Petrology Geochemistry - Geodynamics. Springer, Berlin Heidelberg: New York, 2005.

[11] Peccerillo, A.; Frezzotti, M.L.; De Astis, G.; Ventura, G. Modeling the magma plumping system of Vulcano (Aeolian Island, Italy) by integrated fluid-inclusion geobarometry, petrology and geophysics. Geology, 2006, 34, 17-20.

[12] Peccerillo, A.; Dallai, L.; Frezzotti, M.L.; Kempton, P.D. Sr-Nd$\mathrm{Pb}-\mathrm{O}$ isotopic evidence for decreasing crustal contamination with ongoing magma evolution at Alicudi volcano (Aeolian Arc, Italy): implications for style of magma-crust interaction and for mantle source compositions. Lithos, 2004, 78, 217-233.

[13] Ventura, G.; Vilardo, G.; Milano, G.; Pino, N.A. Relationships among crustal structure, volcanism and strike-slip tectonics in the Lipari-Vulcano Volcanic Complex (Aeolian Islands, Southern Tyrrhenian Sea, Italy). Phys. Earth. Planet. Inter., 1999, 116, 31-52.

[14] Ghisetti, F. Relazioni tra strutture e fasi trascorrenti e distensive lungo i sistemi Messina-Fiumefreddo, Tindari-Letojanni e AliaMalvagna (Sicilia nord-orientale): uno studio microtettonico. Geol. Romana, 1979, 18, 23-58.

[15] Panza, G.F.; Pontevivo, A.; Chimera, G.; Raykova, R.; Aoudia, A. The lithosphere asthenosphere: Italy and surroundings. Episodes, 2003, 26, 169-174.

[16] De Astis, G.; Peccerillo, A.; Kempton, P.D.; La Volpe, L.; Wu, T.W. Transition from cal-alkaline to potassium-rich magmatism in subduction environments: geochemical and $\mathrm{Sr}, \mathrm{Nd}, \mathrm{Pb}$ isotopic constraints from the Island of Vulcano (Aeolian Arc). Contrib. Mineral. Petrol., 2000, 139, 684-703.

[17] Morelli, C.; Giese, P.; Cassinis, R.; Colombi, B.; Guerra, I.; Luongo, G. Scarascia, S.; Schutte, K.G. Crystal structure of Southern Italy. A seismic refraction profile between Puglia-Calabria-Sicily. Boll. Geofis. Teor. Appl., 1975, 12, 275-309.

[18] Santo, A.P. Volcanological and geochemical evolution of Filicudi (Aeolian Islands, south Tyrrhenian Sea, Italy). J. Volcanol. Geoth. Res., 2000, 96, 79-101.

[19] Tranne, C.A.; Lucchi, F.; Calanchi, N.; Rossi, P.L.; Campanella, T.; Sardella, A. Geological map of the island of Filicudi (Aeolian Islands). L.A.C. Firenze, 2002.

[20] Santo, A.P.; Chen, Y.; Clark, A.H.; Farrar, E.; Tsegaye, A. ${ }^{40} \mathrm{Ar} /{ }^{39} \mathrm{Ar}$ ages of the Filicudi island volcanics: implications for the volcanological history of the Aeolian Arc, Italy. Acta Vulcanol., 1995, 7(1), 13-18.

[21] De Rosa, R.; Guillou, H.; Mazzuoli, R.; Ventura, G. New unspiked $\mathrm{K}$-Ar ages of volcanic rocks of the central and western sector of the Aeolian Islands: reconstruction of the volcanic stages. J. Volcanol. Geotherm. Res., 2003, 120, 161-178.

[22] Peccerillo, A.; Taylor, S.R. Geochemistry of Eocene calc-alkaline rocks from Kastamonu area, Northern Turkey. Contrib. Mineral. Petrol., 1976, 58, 63-81.

[23] Santo, A.P. Contribution of clinopyroxene EMP and SIMS data to the understanding of magmatic processes: an example from Filicudi Island (Aeolian Arc, Southern Tyrrhenian Sea). Neves Jahrburch für Mineralogie. Abhandlungen, 1998, 173, 207-231. 
[24] Santo, A.P.; Jacobsen, S.B.; Baker, J. Evolution and genesis of calc-alkaline magmas at Filicudi volcano, Aeolian Arc (Southern Tyrrhenian Sea, Italy). Lithos, 2004, 72, 73-96.

[25] Mattey, D.P.; Macpherson, C.G. High-precision oxygen isotope microanalysis of ferromagnesian minerals by laser fluorination. Chem. Geol., 1993, 105, 305-318.

[26] Mattey, D.P. Laser Prep: An Automatic Laser-Fluorination System for Micromass 'Optima' or 'Prism' Mass Spectrometers. Micromass. Appl. Note, 1997, 107, 1-7.

[27] Bence, A.E.; Albee, A.L. Empirical correction factors for the electron microanalyses of silicates and oxides. J. Geol., 1968, 76, 382483.

[28] Taylor, H.P.; Sheppard, Jr, S.M.F.; Rocks, I. Processes of isotopic fractionation and isotope systematics. In: Stable isotopes in high temperature geological processes. Valley, J.W.; Taylor, H.P. Jr.; O'Neil, J.R. Eds.; Rev. Mineral., 1986, 16, 227-271.

[29] Chiba, H.; Chacko, T.; Clayton, R.N.; Goldsmith, J.R. Oxygen isotope fractionations involving diopside, forsterite, magnetite, and calcite; application to geothermometry. Geochim. Cosmochim. Acta, 1989, 53, 2985-2995.

[30] Matthews, A.; Stolper, E.M.; Eiler, J.M.; Epstein, S. Oxygen isotope fractionation among melts, minerals and rocks. Mineral. Mag., 1998, 62, 971-972.

[31] Zhao, Z.F.; Zheng, Y.F. Calculation of oxygen isotope fractionation in magmatic rocks. Chem. Geol., 2003, 193, 59-80.

[32] Harmon, R.S.; Hoefs, J. Oxygen isotope heterogeneity of the mantle deduced from global ${ }^{18} \mathrm{O}$ systematics of basalts from different geotectonic settings. Contrib. Mineral. Petrol., 1995, 120, 95-114.

[33] Hildreth, W.; Moorbath, S. Crustal contributions to arc magmatism in the Andes of Central Chile. Contrib. Mineral. Petrol., 1988, 98, 455-489.

[34] Esperança, S.; Crisci, G.M.; De Rosa, R.; Mazzuoli, R. The role of the crust in the magmatic evolution of the island of Lipari (Aeolian Islands, Italy). Contrib. Mineral. Petrol., 1992, 112, 450-462.

[35] Kerr, A.C.; Kempton, P.D.; Thompson, R.N. Crustal assimilation during turbulent magma ascent (ATA): new isotopic evidence from the Mull Tertiary lava succession, N.W. Scotland. Contrib. Mineral. Petrol., 1995, 119, 142-154.

[36] James, D.E. The combined use of oxygen and radiogenic isotopes as indicators of crustal contamination. Ann. Rev. Earth Planet. Sci., 1981, 9, 311-334.

[37] De Paolo, D.J. Trace element and isotopic effects of combined wall rock assimilation and fractional crystallization. Earth Planet. Sci. Lett., 1981, 3, 189-202.

[38] Huppert, H.E.; Sparks, R.S.J. Cooling and contamination of mafic and ultramafic magmas during ascent through continental crust. Earth Planet. Sci. Lett., 1985, 74, 37-386.

[39] Peccerillo, A. Plio-Quaternary magmatism in central-southern Italy: a new classification scheme for volcanic provinces and its geodynamic implications. In: Geological and geodynamic evolution of the Appennines. Barchi, R.M.; Cirilli, S.; Minelli, G. Eds.; Boll. Soc. Geol. Ital. Spec., 2002, Vol. 1, pp. 113-127.

[40] Devey, C.W.; Cox, K.G. Relationship between crustal contamination and crystallisation in continental flood basalt magmas with special references to the Deccan Traps of Western Gats, India. Earth Planet. Sci. Lett., 1987, 84, 59-68.

[41] Peccerillo, A.; Wu, T.W. Evolution of calc-alkaline magmas in continental arc volcanoes: evidence from Alicudi, Aeolian Arc (Southern Tyrrhenian Sea, Italy). J. Petrol., 1992, 33, 1295-1315.

[42] Peccerillo, A.; Kempton, P.D.; Harmon, R.S.; Wu, T.W.; Santo, A.P.; Boyce, A.J.; Tripodo, A. Petrological and geochemical characteristics of the Alicudi volcano, Aeolian Islands, Italy: Implications for magma genesis and evolution. Acta Volcanol., 1993, 3, 235-249.

[43] Cox, K.G.; Hawkesworth, C.J.; Geochemical stratigraphy of the Deccan traps, at Mahabaleshwar, Western Gats, India, with implications for open system magmatic processes. J. Petrol., 1985, 26 , 355-77.

[44] Nazzareni, S.; Molin, M.; Peccerillo, A.; Zanazzi, P.F. Volcanological implications of crystal chemical variations in clinopyroxenes from the Aeolian Arc (Southern Tyrrhenian Sea, Italy). Bull. Volcanol., 2001, 63, 73-82.

[45] Gill, J.B. Orogenic andesites and plate tectonics. Springer: Berlin, 1981.

[46] Kessel, R.; Schmidt, M.W.; Ulmer, P.; Pettke, T. Trace element signature of subduction-zone fluids, melts and supercritical liquids at $120-180 \mathrm{~km}$ depth. Nature, 2005, 437, 724-727.

[47] Doglioni, C., Innocenti, F.; Mariotti, G. Why Mt. Etna? Terra Nova, 2001, 13, 25-31.

[48] De Astis, G.; Ventura, G.; Vilardo, G. Geodynamic significance of the Aeolian volcanism (Southern Tyrrhenian Sea, Italy) in light of structural, seismological, and geochemical data. Tectonics, $\mathbf{2 0 0 3}$ 22(4), 1040.

[49] Francalanci, L.; Manetti, P.; Peccerillo, A.; Keller, J. Magmatological evolution of the Stromboli volcano (Aeolian Arc, Italy): inferences from major, trace element and $\mathrm{Sr}$ isotopic characteristics of lavas and pyroclastic rocks. Acta Volcanol, 1993, 3, 127-151.

[50] Gertisser, R.; Keller, J. From basalt to dacite: origin and evolution of the calc-alkaline series of Salina, Aeolian Arc, Italy. Contrib. Mineral. Petrol., 2000, 139, 607-626.

[51] Rottura, A.; Del Moro, A.; Pinarelli, L.; Petrini, R.; Peccerillo, A.; Caggianelli, A.; Bargossi, G.M.; Piccarreta, G. Relationships between intermediate and acidic rocks in orogenic granitoids suites: petrological, geochemical and isotopic $(\mathrm{Sr}, \mathrm{Nd}, \mathrm{Pb})$ data from $\mathrm{Capo}$ Vaticano (southern Calabria, Italy). Chem. Geol., 1991, 92, 153 176.

[52] Barberi, F.; Gandino, A.; Gioncada, A.; La Torre, P.; Sbrana, A. Zenucchini, C. The deep structure of the Eolian arc (FilicudiPanarea-Vulcano sector) in light of gravity, magnetic and volcanological data. J. Volcanol. Geotherm. Res., 1994, 61, 189-206.

[53] Peccerillo, A.; Donati, C.; Santo, A.P.; Orlando, A.; Yirgu, G.; Ayalew, D. Petrogenesis of silicic peralkaline rocks in the Ethiopian Rift: geochemical evidence and volcanological implications. J. Afr. Earth Sci., 2007, 48, 161-173.

[54] De Astis, G.; La Volpe, L.; Peccerillo, A.; Civetta, L. Volcanological and petrological evolution of Vulcano Island (Aeolian Arc, southern Tyrrhenian Sea). J. Geophys. Res., 1997, 102, 8021-8050. 